\title{
What's new? An update from Pittsburgh
}

\section{ACRL's 7 th National Conference was a buge success}

$\mathbf{F}$ ocusing on the customer and the impact of technology were the everpresent themes running through many of the sessions at ACRL's 7th National Conference, "Continuity and Transformation: The Promise of Confluence," in Pittsburgh, March 29-April 1, 1995.

Gray skies and rainy weather did not dampen the enthusiasm of the 2,721 participants. Nearly 1,800 librarians representing all 50 states and eight foreign countries participated in the four theme sessions, 54 contributed papers, 31 panel sessions, 31 roundtable discussions, and 60 poster sessions. Close to 200 companies brought 614 exhibitors and 313 individuals took advantage of ACRL's free exhibits pass to tour the collection of proclucts and services available to academic libraries.

Roundtable cliscussions, a new program offering at an ACRL National Conference, attracted over 300 participants at the very early hour of 7:30 a.m. Many of the participants commented that this was a great way to really talk to people and to find out how libraries around the country are dealing with issues.

ACRL's first silent auction attracted bids on 62 items ranging from getaway weekends to computer software. Funds from the auction will be used to establish an endowment to support the development of leaclership skills among entry-level librarians.

The All-Conference Reception held at the Carnegie Museum offered a sumptuous array of desserts, live jazz and classical music, and the opportunity to tour many of the museum's exhibits. Participants enjoyed the reception so much that they were heard saying, "ACRL will never top this!"

CERL News is pleased to offer the following summaries of some conference programs thanks to the volunteer efforts of many of the participants. Part two of this article will appear in the July/August issue. If you would like more detail about these sessions, the contributed papers will be published in the Conference Proceedings due out by the end of June, and many of the sessions were audiotaped (see the insert in this issue for a list of available tapes).

\section{Building a 21 st-century mind}

Society is in the midst of dramatic change and cultural anthropologist Jennifer James believes that librarians can enable people to briclge the "technological, economic, demographic, cultural abyss" forming between current systems and those required for the future. "It is hard for me to imagine a single profession in the world that is going to change more rapiclly than yours - and already has. What you're going to have, of course, is chaos." Any stable system must change and grow, or it will break down. "Chaos is the self-organizing process of new systems. Out of chaos will come stability, then chaos again."

In order to survive rapid change, people must develop a new mind "to tear down the systems that they have built themselves with integrity and hard work." To do so, they must give up the "myths" to which they cling in an effort to make reality manageable. James gave

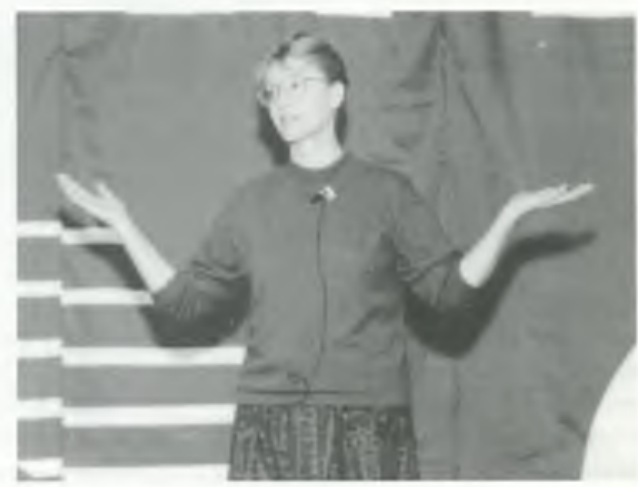

Jennifer James explains the change process. 
racism as an example of a myth that will be increasingly dysfunctional as a tool in dealing with reality. Changing consciousness changes society's myths and language: "calling someone a Native-American instead of a savage means treating the person differently." Disintegration of the family, drug use, and violence are symptoms of people continuing to base decisions on mythology, unable to deal with the chaos they experience.

James encourages us to expand our perspectives and keep our senses of humor, for we must deal with the anxiety, resistance, and anger that are part of the grieving process naturally accompanying change. Because librarians deal with information, they may be among the first to notice new patterns and language, and be in a position to guide others,-Helen $H$. Spalding, University of Missouri-Kansas City

\section{Hiroshima bombing a racial tragedy}

In these days when America is experiencing the pressure of racism, it was timely for ACRL to have Ronald Takaki, an expert on ethnic studies from the University of California at Berkeley, share his research on "Why the Americans Dropped the Bomb on Hiroshima."

Takaki mentioned the two theories behind the studies of the bombing, namely, the "end the war theory" and the "cold war

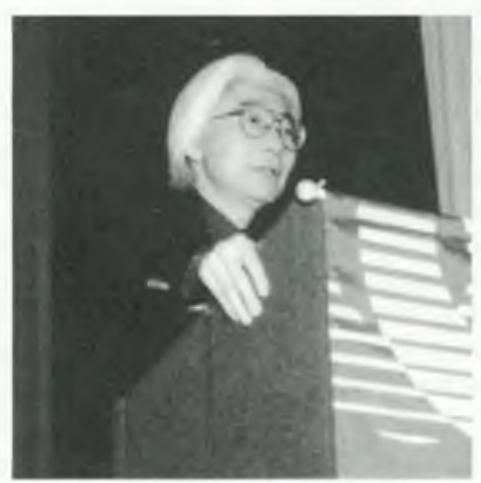

Ronald Takaki stressed the need for multicultural education. events that changed the world. He ended his speech by challenging librarians with very powerful "what if" questions: "What if there had been a multicultural curriculum in our schools and colleges at the time Truman was growing up?" and "What if stereotypes had been challenged intellectually in a multicultural curriculum and also in a library that presented multicultural knowledge?"-Rochelle D. Amores, University of California, San Marcos

\section{The interconnectedness of local and global processes}

Author and professor Saskia Sassen spoke on "The Global City: Place, Production, and the New Centrality." Sassen detailed her insights into the nature and impact of globalization. She discussed the "false dichotomy between the local and the global," and referred to the common perception in business, politics, industry, and other arenas that developments on the global level are separate from local processes. Her findings reveal the interconnectedness of local and global processes.

Sassen also pointed out the inaccuracy of the view that globalization is causing dispersal from cities and centers. She said that cities are reemerging as centers of business and social activities because of the growing need to have immediate access to a community of (human) experts. Sassen specutheory," but also stressed the racial context within this event. He discussed his research on President Truman's background and opinions, including his negative views on other races, and cited these as possible reasons for deciding to homb Hiroshima. Takaki stressed that the lack of multicultural education during that time led to this disaster which could have been prevented. According to him, Truman's lack of knowledge and understanding of "people from different shores" proved to be the distinguishing factor for making such a dreadful decision. He asserted that Truman "had little or no social or intellectual opportunities to challenge his prejudiced views" at that time.

Takaki said that the importance of the librarian's archival role in preserving documents makes it possible for historians to study the lated that libraries will benefit from this reemergence of cities.

Audience questions probed the impact and relationship of this research on libraries. Sassen pointed to the shift in libraries from collections to access of information. "The risk is in the loss of connection with the locality. Access reduces the difference between libraries." Another risk posited was that the information superhighway may "create a new geography of marginality like a greyhound bus route."

Patricia Breivik (Wayne State University) made some very cogent remarks at the end of Sassen's talk. She gave the example of small businesses that have great need for local information which is not available on the information highway. At the same time, however, global affairs affect local businesses more than ever. 
"We always hear that now with all these new technologies we won't need libraries anymore. Your research gives us better answers for that. We can help people weed through all the information out there."-Charlotte Hess, Indiana University

\section{Predictions for the 21 st century}

National Public Radio reporter John McChesney rounded out the conference with "Tech-

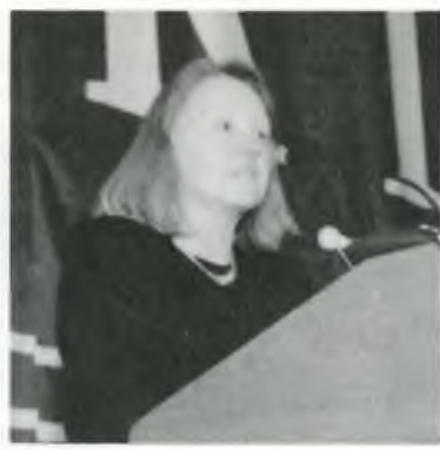

Saskia Sassen predicted libraries will benefit from a growth of cities.
Measuring user perceptions of library services Tom Fry's (University of Denver) paper on "Undergraduate Perceptions of Library Service: Use of Focus Groups and Surveys in Strategic Planning" described a 1993 study at UCLA on undergraduates' needs and perceptions. Two different study methods were used: focus groups and questionnaires. The focus groups used open-ended questions to look at several areas of connology and the Service-Centered Library." McChesney discussed a number of topics related to the impact of digital technologies on the library of the future: books and periodicals, copyright law, systems of payment on the Net, and the importance of establishing universal standards for machine-readable text ("proprietary languages are the bane of the information age").

McChesney began by relating MIT professor Nicholas Negroponte's opinion that, in the future, electronic books will replace paper ones (from Being Digital, Knopf, 1995) and weighed this rosy view of the Internet against Clifford Stoll's more pessimistic statement that libraries are spending too much money on "machinery" and not enough on periodicals and books (from Silicon Snakeoil, Doubleday, 1995). He then offered his own opinion that books may be with us for a while, but the "molecular era of periodicals that have to be stored on a shelf" is coming to an end, replaced by an age when all periodicals will be available in electronic form.

McChesney then turned to the hotly debated question of setting up a National Electronic Library, adding that if libraries "with their tradition of open access" don't set up this library, then commercial providers will, and will "charge a hefty fee for using it, and further divide us into a nation of information haves and have nots." He ended his speech with the cautionary note: "I hope you guys are ready for a fight on this one."-Jack Helbig, ACRL

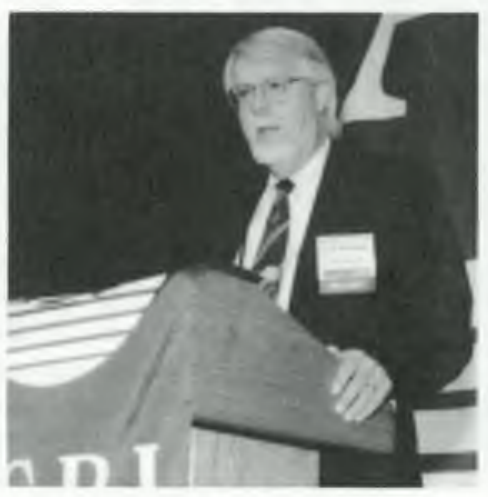

John McChesney urged librarians to set up a National Electronic Library. cern: usage, services, workshops, and additional services. Findings included: the need to advertise services (students were unaware of what was available); that $60 \%$ of students said they would not attend library workshops but wanted access to a librarian when they had a question; and that students felt the online catalog was "user-hostile." The implications for strategic planning included the need to tailor services to customers' needs instead of wasting resources (i.e., more signs, handouts, and one-on-one reference; less workshops).

Danuta Nitecki's (University of Maryland at College Park) study on "User Expectations for Quality Library Services Identified through Application of the SERVQUAL Scale in an Academic Library" asked: "What is most essential to users for delivery of excellent library service?" and "What is most important to users in their evaluation of quality of library service?" To answer this she used the SERVQUAL instrument which has five service-quality dimensions and offers a method to measure customer perceptions of service quality; 544 questionnaires were mailed and 351 returned for a response rate of $63.6 \%$. Of the five dimensions, reliability was ranked first followed by responsiveness, empathy, and assurance. Tangibles (physical facilities) were lowest. SERVQUAL is a valid instrument to apply to academic service settings because it helps managers focus on organizational barriers that need to be overcome to improve service quality, but interpretation of 
the dimensions should be made with care.Jacqueline Borin, California State University, San Marcos

\section{Design of the wired library}

Design assumptions and implications for integrating advanced technology into new libraries were described in "The Integrated Library: Designing Learning Spaces to Utilize Advanced Technology and Networked Information." Assumptions included the need for: increased collaborative learning spaces; clustered, networked workstations; labs for user instruction; power and networking connections; and remote user support. A related premise: text will not soon replace paper. Four newly planned facilities were showcased.

Susan Barnes (Cornell University) described the struggle librarians had with the question: "The virtual library is imminent; why build?" Based on the current facility, the reasons include: inadequate power, network connections, and space for electronic equipment such as workstations and file servers; crowded conditions in stack areas that can't absorb new acquisitions; full-text is still in primitive form; and the study atmosphere expected by students is not provided elsewhere.

Charlene Hurt described George Mason University's facility is a "marketplace of ideas." An open concept building, it contains group study areas equipped with network connections, a multimedia center, and student authoring lab. It shares space with other campus entities such as the bookstore.

David Lewis said that Indiana UniversityPurdue University Indianapolis provides 20

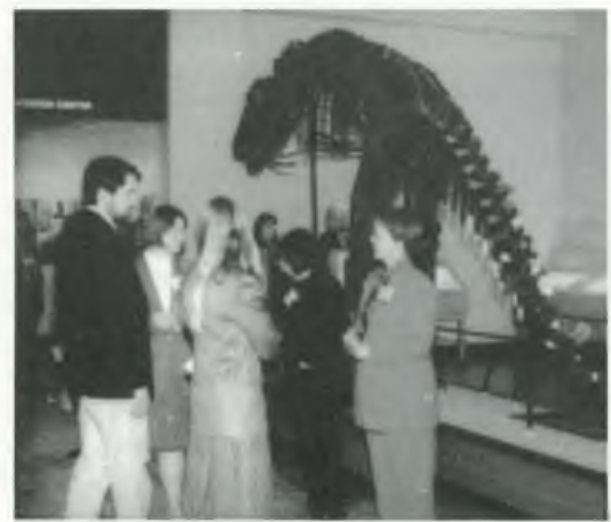

A dinosaur listens in on conversation at the AllConference Reception at the Carnegie Museum. laptops for student checkout and a tiered collection of workstations located strategically throughout a building that contains over 1,700 data connection sites.

Philip Tompkins said that at Estrella Mountain Community College the library is known as the Campus Information Center, where collections are primarily electronic and highly networked.-Carolyn Gaskell, Walla Walla College

\section{Managing electronic information}

"A New Service from Libraries: Electronic Publishing" was Gail McMillan's (Virginia Polytechnic Institute and State University) chronicle of the Scholarly Communications Project, a unit of the Virginia Tech University Libraries devoted to Internet publishing activities. The project has, in just four years, become host to a full array of digital resources and services that constitute what McMillan refers to as a "virtual branch library." Few in number but dedicated in purpose, project staffers have accomplished these bold initiatives "without demanding more from the library's budget." Traditional library values are at the core of the project, yet improvements to both access and service motivate this pioneering endeavor.

Technical services librarians have skills that translate well to the electronic environment, said Marijo Wilson (Cornell). Her firsthand knowledge of database cataloging and management issues was reported in "Mainstreaming Electronic Numeric Data Files: The Impact on Technical Services." Cornell's two successful efforts to mount specialized statistical databases were undertaken with active input from technical services librarians. Integrating numeric data files into the collection requires greater technical proficiency on the part of all personnel, and it is being accomplished using in-house expertise and individual study. The results are positive for staff and patrons alike.-Mary Hubbard, University of lowa Libraries

\section{Electronic classrooms and teaching the Internet}

With a wide array of databases and gateways available on their campus system, librarians at University of California, Santa Barbara (UCSB), wanted to offer hands-on training that only a networked electronic classroom could provide. With a grant from their institution, they remodeled a work space at a total cost of about $\$ 106,000$. In "Roadsigns on the Electronic Highway: Teaching Access to Computerized Infor- 


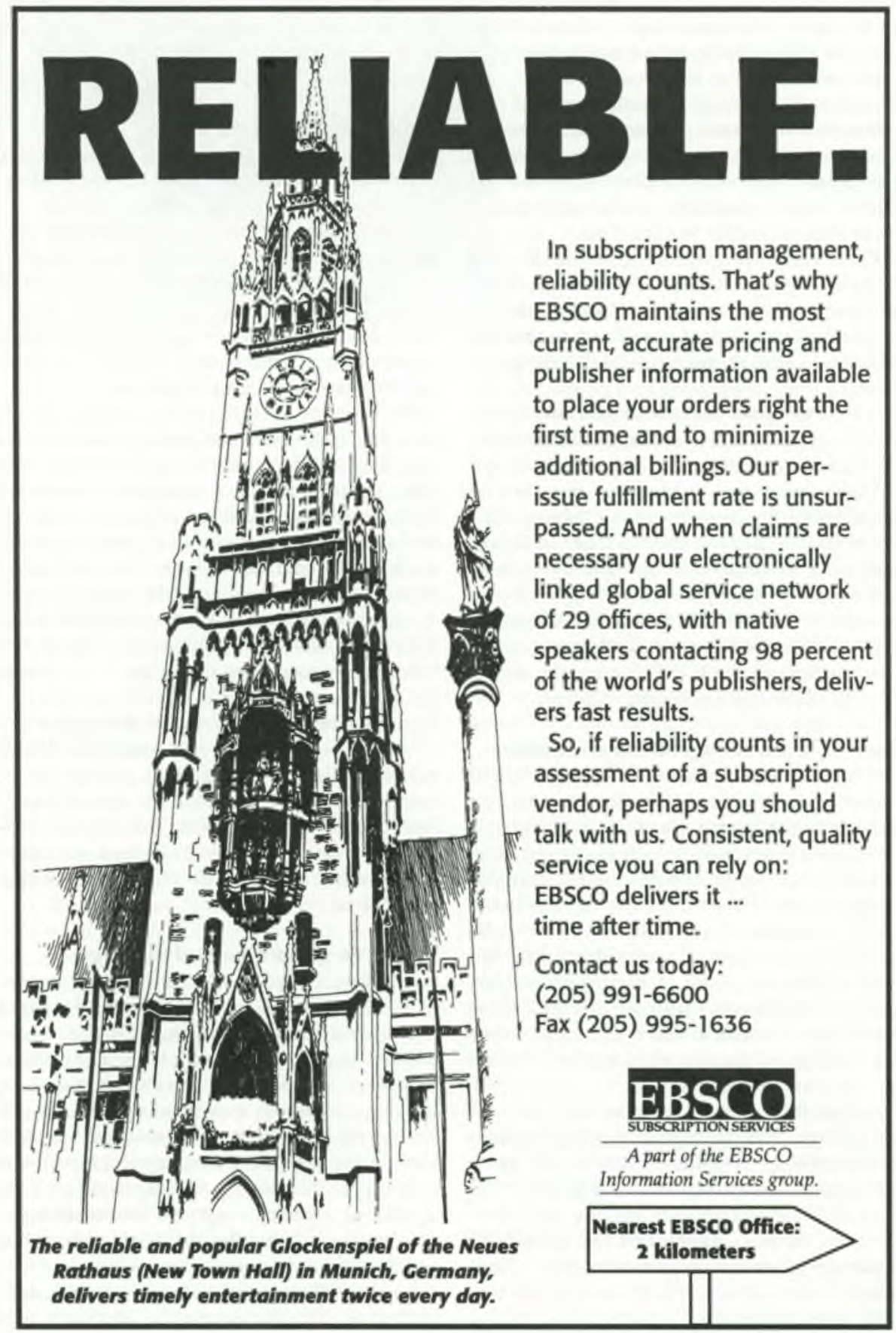


mation," Cheryl LaGuardia (Harvard University) emphasized that one of the best decisions they made was to purchase a high-resolution Sharp projector with a ceiling mount and a good projection screen.

Once the electronic classroom was in use, they found that team teaching was essential. When students began working on assignments individually, they needed an immense amount of help, and a low student/teacher ratio yielded better and more effective learning.

Chris Oka (UCSB) discussed the library's publication program in which reference librarians were asked to compile subject guides for their selection area. Staff members were trained on various software packages in the electronic classroom. The documents they procluced were provided in print form and loaded on the library's gopher, thus serving two audiences: the walk-ins and the remote electronic users.

These same two audiences can also be served by the library skills tutorial "Library 101," which is mounted on their gopher and provides basic information about library resources and research strategies. Users can pick and choose the information they want and telnet links can be adided as needed. Plans to convert these documents to HTML format are underway._Debbie Malone, Ursinus College

\section{How to foster campus collaboration}

Tara Lynn Fulton (Bucknell University) chaired a panel called "Cultural Diversity and Synergy: Collaboration Between Librarians and Academic Computer Center Staff" which examined ways to develop a collaborative relationship between computing and library personnel. It was noted that the best results will accrue when we "take maximum advantage of our differences." We need to become aware of each person's personality and gifts and make use of strengths on teams and committees. Stereotyping each other and having ambiguous roles are two factors that hamper cooperation.

Suggestions of ways to increase collaboration include: having regular meetings or luncheons to plan or train; serving on the same committees; socializing; working together on mutually beneficial projects; inviting each other to events; having a technology fair; putting on workshops together; and team teaching. Some universities put both service units under one organizational head.

Flexibility and attention to user needs are key ingredients that will support new ways of teaching and learning. In the future, synergy between computing and library personnel will further their joint mission of assisting campus users to maximize access to information.Deleyne Wentz, Utah State University

\section{Publishing? Just do it!}

James Neal (Indiana University) moderated a lively panel discussion called "Library Publishing in the 90's: Future Generations Will Ask . . The initial focus of the session was on the current state of library publishing: the move to more journal articles and less monographs; more practical research and less empirical study. Some discussion centered on technological advances such as listservs and electronic journals and their influence on publishing.

Participants agreed on the need for more meaning in the literature; authors need to analyze data and draw conclusions for the profession. Each editor gave examples of articles they'd like to see written: problem and solution articles; commentary on solutions that dicln't work; and solid, quantitative research that makes a case for libraries to the outside world.

Advice to potential authors: you should consider "why anyone would want to read this" before beginning, then send ideas to the editorial staff. If the concept is a good one, the editors will work with you on the writing.

Advice to administrators: support staff in their publishing efforts by putting a priority on research and supporting them via money, inspiration, time to think and write, consultation support services, and rewards and recognition.-Nancy A. Wootton, Indiana University South Bend

\section{VIVA: Virginia's virtual library}

In "Statewide Virtual Library Planning in Virginia: Comerstones and Components," the panel reported on the development of Virginia's statewide virtual library. Nancy Marshall (College of William and Mary), a member of the VIVA steering committee, explained that the project was based on the following assumptions: that cooperative collection development is possible only if prompt delivery of requested materials is assured, that the equity of information access is essential, that the plan work without the creation of a new central bureaucracy, and that the virtual library be accessible to scholars throughout Virginia. An early challenge was to provide a common interface to various online catalogs. 


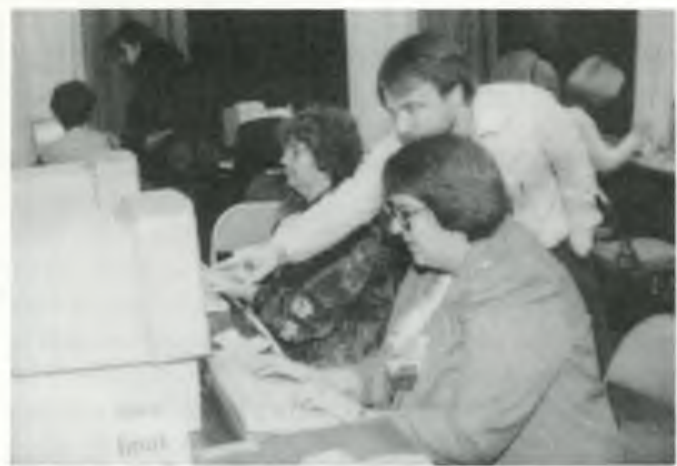

The Internet Room enabled participants to stay in touch electronically.

Access (20 ports: first-come, first-served) to 11 databases through OCLC's FIrstSearch was provided during the first year of the project. Local projects that could easily be brought online contributed to the project's early success.

Online access to full-text databases, including the Chadwyck-Healey poetry series and an online encyclopedia, are planned. To explore VIVA, connect using your favorite Internet web server: http://www.vcu.edu/ulsweb/viva/ viva.html.-Michele B. Wolfe, West Chester Uni versity

\section{Careers in academic libraries: Staff and librarians}

Kathlin L. Ray (University of the Pacific) discussed hiring and recruitment procedures for staff positions in academic libraries in "Toppling Hire-archies: Support Staff and the Restructured Library." She suggested that in the past libraries have tended to look at measurable tasks and skills in the hiring process, and have tended not to look at "the whole person" in recruitment. Because we need staff members who can see the larger picture and can adapt to the changing library environment, she maintained, we need to rethink how we recruit and hire them; we need to ask ourselves if a particular position will provide meaningful work for an intelligent and responsible person (particularly if we are requiring a college degree). In conclusion, she suggested that we need more lively and descriptive job ads, as well as more open and fluid staff jobs.

In her presentation on career paths for librarians, "Comparable Rewards: Librarian Career Paths," Maralyn Schad (Wichita State University) focused on the predominant view that in order for librarians to advance their careers they need to take on administrative responsibilities. She noted that despite a 1974 ALA Council resolution affirming comparable rewards for both administrative and service employment in librarianship, little has changed in the academic library environment regarding the status and financial rewards attached to these career paths. She suggested that some individuals drawn to librarianship might not want to manage, and as a profession we should be sophisticated enough to recognize this fact. Schad suggested that "there must be space for both the manager and the student-oriented scholar educator" in librarianship.Jean McGruer Parker, St. Louis University

\section{Academic libraries can help keep students in school}

With a smaller pool of qualified applicants, student retention at colleges and universities has become a major campus issue and speakers at the "Academic Libraries and Student Retention" panel asserted that libraries can play a vital role in keeping students in school. Cheryl Beil (George Washington University) stated that universities must look at the characteristics of their student body, including family life, because this will affect each student's integration into the university community, especially with the increasing diversity of student bodies. Beil also stated that "retention is tied into a very broad student experience."

At GWU's Gelman Library, Debbie Masters instituted a variety of activities to encourage its use and help it become part of a student's broader experience. These activities include: library involvement in new student orientation, publishing a library calendar, sponsoring faculty author readings at the library, and creating Café Gelman, a once-a-semester coffeehouse within the library. Masters suggested that libraries present their interest in participating in student activities to the campus community by stating the ways in which those activities will enhance the university's goals of integrating students into the community.-Shellie Jeffries, University of Illinois at Urbana-Champaign

\section{Libraries are for users}

In "The User-Centered Library and Library Community Analysis: Making It Happen," Betsy Wilson, Steve Hiller, Nancy Huling, and Carla Rickerson (University of Washington) offered participants a session which they hoped would 
be engaging, interactive, meaty, and fun. The group came through with flying colors on all counts! Building on work at the university for the past three years, they shared information on how they developed their definition of the user-centered library, how they have determined services can best be provided, how they have evaluated services, and how they hope to sustain services in a changing environment. Participants were encouraged to offer views and solutions, both immediately and through future use of the university's new homepage on library assessment.-Nancy H. Seamans, College of Health Sciences

\section{Using patron surveys in the library}

In order to vary the format of the panel on "Customer Input into Library Decision-Making," Northwest Missouri State University (NMSU) librarians Connie Ury and Joyce Meldrem responded to Carolyn Johnson's (also from NMSU) questions about the user surveys they developed in their library to determine what their customers need and want from the library staff. The three target audiences were English students, English faculty, and the library's student employees.

Ury and Meldrem gave detailed information regarding the kinds of questions asked, the number of responses received, and the ways that the information gleaned from the surveys led to changes in library operations. Among many other things, they found that open-ended questions frequently elicited meaningful responses and that the employees were the easiest audience to survey. A useful handout included samples of the survey questions.

As a result of the infor mation gathered from the surveys, practical and detailed changes have been made in the bibliographic instruction curriculum and the library work environment. The target audi-

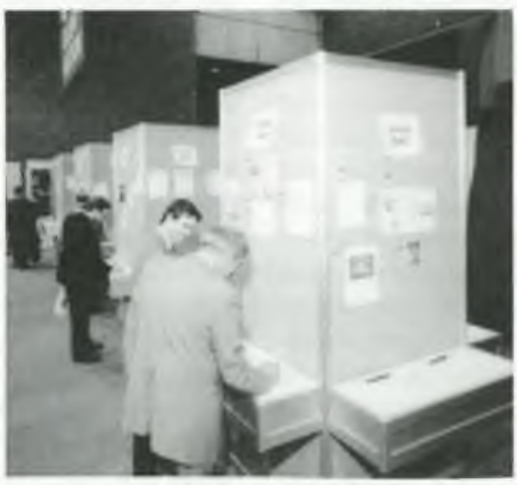

Participants survey the items offered at ACRL's first-ever silent auction.

\section{Scholarly research and the Infernet}

In the session titled "The Impact of the Internet on the Scholarly Research Process in the Social Sciences and Humanities," Vivienne Monty and P. Warren-Wenk of York University addressed their research into the new technology. Monty began her research with the assumption that the Internet will have an effect on and possibly change reference services. She surmised it also has the potential to change the way research is done. Monty and Warren-Wenk identified 50 heavy users of the Internet in the areas of the humanities and the social sciences. They conducted telephone interviews with them to gather examples of the kinds of research being done by these users via the Internet.

They found that e-mail, the Internet func tion receiving the heaviest use, provides a way of making links with other researchers and serves as an arena for troubleshooting problems. E-mail makes project administration by remote teams possible. Especially important to younger faculty is the fact that communication in this format serves as an "agent of democratization."

Discussion groups, which have become a new form of scholarly discussion, were the second most used Internet resource by researchers in the humanities and social sciences. Ejournals were also considered important because of the reduction in time to bring something to publication and because criticism can be immediate. Also noted were ease and immediacy in subscribing. E-journals have some drawbacks that were noted including the questioning of credibility because they are not considered mainstream, lack of indexing in regular indexes, and lack of recognition for tenure or promotion in most situations.

Based on the Internet users they interviewed, Monty and Warren-Wenk concluded communica- ences were told how their input had made a difference in library procedures. A further outcome of the surveys has been increased support of library programs by English faculty.Anne Pound, Dyersburg State Community College tion patterns in scholarly research are chang ing because of the Internet. It has made communication more timely and more international. However, authenticity and peer review are still seen to be problems. - Mary Barton, Moorbead State University 


\section{The State \\ of the Art}

...working

smart
Leaders in the Information

Industry providing subscription services, article delivery and library automation software.

- REMo Mouse driven serials management system.

- Ross Online ordering, claiming and searching of journal and publisher databases.

- Renewal Express PC-based system to analyze current serials holdings and plan for the future collection development.

- Financial Planner Lotus formatted worksheet to analyze previous spending history and plan future budget allocations.

- UnCover The fastest most comprehensive service for fax delivery of journal articles available today.

- BACKsERv An Internet list devoted to the informal exchange of serial back issues among libraries.

\section{Readmore Academic Services}

700 Black Horse Pike, Suite 207

Blackwood, NJ 08012

Phone: 1-800-645-6595

Fax: 609-227-8322 